\title{
CORRELATION BETWEEN NOX AND CO EMISSIONS AND ACTIVATION ENERGY OF RENEWABLE FUELS.
}

\author{
Charles C Conconi ${ }^{1}$, Paula Manoel Crnkovicr ${ }^{1.2}$ \\ ${ }^{1}$ University of São Paulo - Mechanical Engineering Department - São Carlos, Brazil \\ ${ }^{2}$ Universidade Estadual Paulista - UNESP -Institute of Chemistry - Araraquara - Brazil \\ E-mails: charles.conconi@daimler.com, paulamcrn@gmail.com
}

\begin{abstract}
Biofuels have been widely used in conventional Diesel engines to replace, partially or totally, by fossil diesel. However, the use of an innovative fuel should be evaluated and an important feature to be considered is the ignition delay of the combustion process. Ignition delay can be correlated with activation energy $(\mathrm{Ea})$ and greatly affects the performance of the engine, including pollutant emissions. This study presents the determination of activation energy of three pure fuels - farnesane, biodiesel and fossil fuel - and their blends. In addition, the correlation between $\mathrm{Ea}$ and NOx and $\mathrm{CO}$ emissions were established. Gases emissions were generated in the OM 926 LA CONAMA p7/EURO 5 diesel engine according to the European Stationary Cicle (ESC). Activation energies were determined by means of thermogravimetric experiments and the mathematic model free-kinetics. Our results indicate that when biodiesel is added to the blend with fossil Diesel, both activation energy values and NOx emission increase, but no direct correlation between $\mathrm{Ea}$ and $\mathrm{CO}$ emissions was observed. A contrary behavior was observed with farnesane in the blend, i.e., its addition in the fossil Diesel decreases both activation energy and NOx and CO emissions.
\end{abstract}

\section{INTRODUCTION}

The reduction of both the dependence on fossil fuels and global pollutant emissions has been a worldwide growing concern.

Diesel engine emits several pollutants due to thermal processes such as carbon monoxide $(\mathrm{CO})$, carbon dioxide $\left(\mathrm{CO}_{2}\right)$, hydrocarbons $(\mathrm{HC})$, nitrogen oxides (NOx) and particulate materials (MP). These pollutants can cause damage to both living beings and environment, which makes important to evaluate the performance and emissions when new fuels and new technologies are proposed.

The use of biofuels and their blends with fossil diesel without physical changes to the engine has been a trend [2]. Emissions are directly influenced by the fuel properties, namely cetane number, density, activation energy, surface tension etc. and factors related to the engine design: compression, injection time, bore, stroke, etc. [2] e [3].

Several studies have been developed to evaluate the emissions of the mixture of diesel and biofuels. [1] showed that the use of the diesel/biodiesel blend presented reduction of $28-46 \%$ of $\mathrm{CO}$, but an increase between $6.95-17.62 \%$ of NOx compared to pure fossil diesel. [4] found that a binary mixture (30\% Farnesane/70\% fossil diesel) reduces $\mathrm{CO}$ emissions, but presents similar NOx emissions compared to the pure fossil diesel.

Other investigation presents the effect of the fuel properties in the pollutant emissions. [5], showed that high NOx emission is due to the oxygen in the chemical composition of the fuel. 
[6] stated that physical properties of the fuel, such as volatility, density, surface tension and cetane number, have secondary impacts on the combustion process.

This study aims to determine activation energy for three different fuels (farnesane, biodiesel and fossil fuel) and their blends at five different percentages $(25 \%, 50 \%, 70 \%, 80 \%$ and 90\%) using thermogravimetric experiments and Model Free Kinetics. In addition, test were conducted in a diesel engine model OM 926 LA CONAMA P7/Euro 5 according to European Stationary Cycle (ESC) to determine CO and NOx emissions.

\section{EXPERIMENTAL}

\subsection{MATERIALS AND METHODS.}

Three different fuel samples, (1) commercial diesel S50 - according to ANP 42/09 [7] namely in this study by (D) sample, (2) renewable diesel from sugar cane named farnesane (F) sample and (3) biodiesel (B) sample were used in this study. Farnesane is a hydrocarbon $\left(\mathrm{C}_{15} \mathrm{H}_{32}\right)$ was supplied by Amyris Brasil S.A. from a pilot plant located in Campinas - State of São Paulo (Brazil) and the soybean biodiesel was supplied by Brasil Ecodiesel from a plant located in Floriano - Piaui State (Brazil).

Properties of the pure samples are detailed in the Table 1 . The elemental analyses were determined on the analyzer Leco CHN 1000 and the high heat value (HHV) was determined on IKA Werke C 2000. Cetane number was measured in an engine according standard ASTM D 613.

Table 1: Properties of the pure fuels

\begin{tabular}{lccc}
\hline Analysis & \multicolumn{3}{c}{ Samples } \\
& Farnesane & Diesel & Biodiesel \\
\hline Carbon (\%) & 84.67 & 85.54 & 76.5 \\
Hydrogen (\%) & 15.33 & 14.46 & 12.74 \\
Oxygen (\%) & - & - & 10.76 \\
Nitrogen (\%) & - & - & - \\
Sulfur (\%) & 0.001 & 0.003 & 0.001 \\
Cetane Number & 58 & 49 & 59 \\
Cinematic Viscosity $40{ }^{\circ} \mathrm{C}\left(\mathrm{mm}^{2} \mathrm{~s}^{-1}\right)$ & 2.95 & 3.11 & 4.42 \\
Density a $20^{\circ} \mathrm{C}\left(\mathrm{g} \mathrm{ml}^{-1}\right)$ & 0.770 & 0.843 & 0.882 \\
High heating value $\left(\mathrm{MJ} \mathrm{kg}^{-1}\right)$ & 46.9 & 45.3 & 39.7 \\
\hline
\end{tabular}

Thermogravimetric experiments were performed in a TA Instrument Q50 balance and the analyses were carried out from room temperature up to $400{ }^{\circ} \mathrm{C}$ at five heating rates: 5.0, 10.0, 15.0, 20.0 and $25.0^{\circ} \mathrm{C} \mathrm{min}{ }^{-1}$. Sample mass of $3.6 \pm 0.5 \mathrm{mg}$ was used for each experiment, in addition, initial mass was kept lower than $4.0 \mathrm{mg}$ in order to avoid effects such as mass and heat transfer during the decomposition of the materials. 
Table 2: Specification of engine.

\begin{tabular}{ll}
\hline Engine make & Mercedes-Benz \\
\hline Engine model & Engine OM926LA E5 \\
Displacement volume & $7.201 \mathrm{~cm}^{3}$ \\
Number of cylinders & 6 in line \\
Power & $240 \mathrm{~kW} @ 2,200 \mathrm{~min}-1$ \\
Torque & $1,300 \mathrm{Nm} @ 1,200$ to $1,600 \mathrm{~min}-1$ \\
Bore & $106 \mathrm{~mm}$ \\
Stroke & $136 \mathrm{~mm}$ \\
Compression ratio & $17.5: 1$ \\
Valves per cylinder & 3,1 intake and 2 exhaust \\
Fuel Injection System & UP Electronic, independent Unit Pumps \\
& + mechanical injectors nozzles \\
After treatment system & SCR (Selective Catalyst Reaction)
\end{tabular}

The atmosphere used was synthetic air with flow rate of $100 \mathrm{ml} / \mathrm{min}$. Experiments were performed in triplicate and the average curve was used for the calculations.

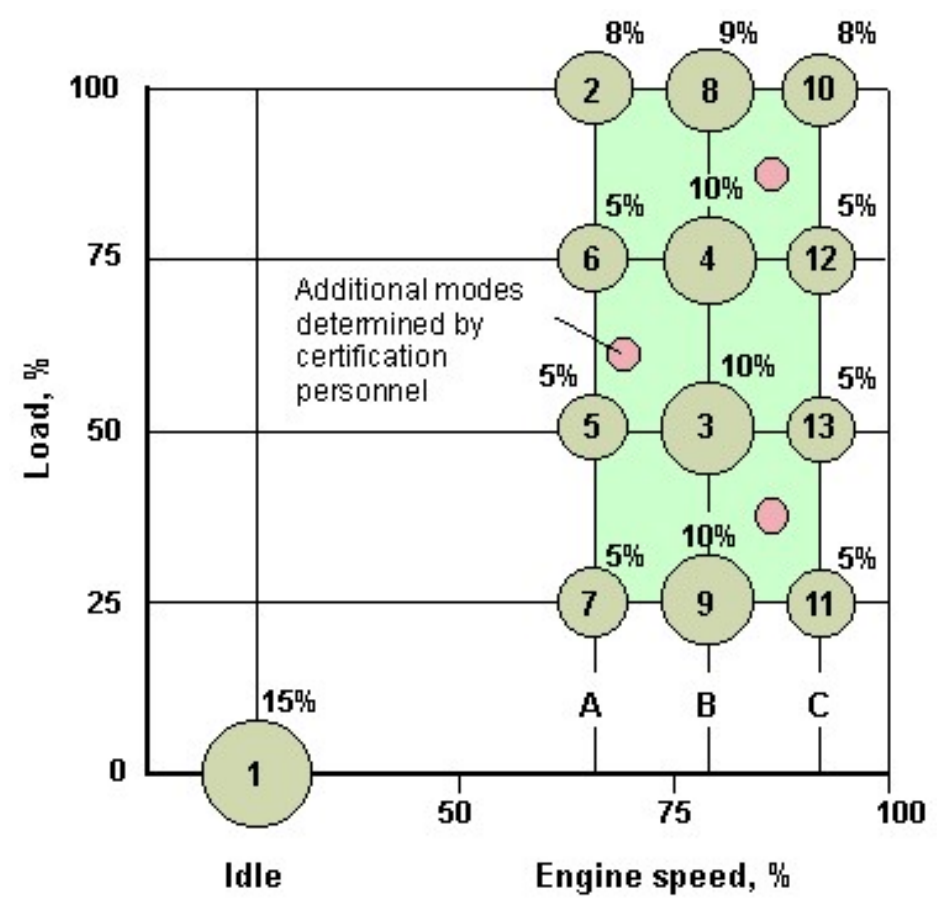

Figure 1 European Stationary Cycle (ESC) (De Jong et al., 2012).

The European Stationary Cycle test (ESC) using a OM 926 LA CONAMA P7/EURO 5 diesel engine according Table 2, was applied to determine $\mathrm{NO}_{\mathrm{x}}$ emission. "Figure 1" depicts the sequence of 13 measurement points concerning the combination of loads $(25,5075$ and $100 \%)$ and speeds $\mathrm{nA}(1,340 \mathrm{rpm}), \mathrm{nB}(1,710 \mathrm{rpm})$ and $\mathrm{nC}(2,080 \mathrm{rpm})$ [8]. Tests have been performed by using blends of biodiesel/diesel and farnesane/diesel . The final value of $\mathrm{NO}_{\mathrm{x}}$ for each pure fuel was determined considering the average of all experiments. 


\subsection{Mathematical model}

Model-free kinetics was used for the determination of the activation energy, this model is based on isoconversional techniques to calculate the activation energy as a function of conversion $(\alpha)$ of the chemical reaction. Thus, this approach was used to follow all the conversions obtained from multiple experiments. This theory is based on "Equation (1)".

$$
\frac{d \alpha}{d t}=k(T) f(\alpha)
$$

Where, $t$ is the time, $T$ the temperature, $f(\alpha)$ the model of the reaction and $k(T)$ is the coefficient of Arrhenius reaction rate. After the necessary adjustments and considerations, as shown in several prior studies [9] e [10] the model Model-free kinetics is represented by "Equation (2)".

$$
\ln \frac{\beta}{T_{\alpha}^{2}}=\ln \left[\frac{R A}{E_{\alpha} g(\alpha)}\right]-\frac{E_{\alpha}}{R_{\alpha}} \frac{1}{T_{\alpha}}
$$

Where $\beta$ is the heating rate, $g(\alpha)$ to an integrated model of reaction and the subscript $\alpha$ represents the values related to a given conversion.

\section{RESULTS}

\subsection{NOX EMISSION.}

Table 3 shows $\mathrm{NO}_{\mathrm{x}}$ emission and $\mathrm{E}_{\mathrm{a}}$ activation energy for pure fossil diesel, farnesane and biodiesel and their blends at five different compositions. It can be noted that when farnesane is added to fossil diesel, $\mathrm{NO}_{\mathrm{X}}$ emission is reduced up to $11.22 \%$ when compared with pure fossil diesel. However, when biodiesel is added to fossil diesel the NOx emission increases up to $21.29 \%$.

According to [11] the majority of the reviewed studies in diesel engine showed that biodiesel and its mixture with diesel has an increasing trend in $\mathrm{NO}_{\mathrm{x}}$ emission, in our study as the percentage of biodiesel increased in the blend, NOx emission increased from 0.32 until $21,29 \%$. However, adding the farnesane to the fossil diesel a reduction of $\mathrm{NO}_{\mathrm{x}}$ from 0,84 until $11.22 \%$, was observed.

$\mathrm{NO}_{\mathrm{x}}$ emissions are described in this study as normalized values considering $100 \%$ of $\mathrm{NO}_{\mathrm{x}}$ emission for the fossil diesel.

In addition, it is interesting to note in the Table 3 that the lowest $\mathrm{NO}_{\mathrm{x}}$ emission was obtained for pure farnesane, the highest $\mathrm{NO}_{\mathrm{x}}$ emission for pure biodiesel and the intermediate values for the blends of both biofuels are added to the fossil diesel. 
Table 3: $\quad E_{a}$ activation energy and NOx emission for diesel, farnesane, biodiesel and their blends

\begin{tabular}{cccccc}
\hline Samples & Diesel & Farnesane & Biodiesel & $\mathrm{E}_{\mathrm{a}}(\mathrm{kJ} / \mathrm{mol})$ & $\mathrm{NO}_{\mathrm{x}}(\%)$ \\
\hline D & 100 & 0 & 0 & $86.69 \pm 8.68$ & $100.000 \pm 0.001$ \\
F10 & 90 & 10 & 0 & $86.25 \pm 8.15$ & $99.155 \pm 0.005$ \\
F20 & 80 & 20 & 0 & $85.80 \pm 7.63$ & $96.006 \pm 0.015$ \\
F30 & 70 & 30 & 0 & $85.36 \pm 7.11$ & $95.617 \pm 0.007$ \\
F50 & 50 & 50 & 0 & $84.47 \pm 6.06$ & $95.003 \pm 0.001$ \\
F75 & 25 & 75 & 0 & $83.36 \pm 4.75$ & $92.134 \pm 0.004$ \\
F & 0 & 100 & 0 & $82.24 \pm 3.44$ & $88.784 \pm 0.004$ \\
\hline B10 & 90 & 0 & 10 & $87.69 \pm 8.19$ & $100.316 \pm 0.001$ \\
B20 & 80 & 0 & 20 & $88.68 \pm 7.71$ & $101.289 \pm 0.003$ \\
B30 & 70 & 0 & 70 & $89.68 \pm 7.23$ & $103.745 \pm 0.002$ \\
B50 & 50 & 0 & 50 & $91.67 \pm 6.26$ & $108.912 \pm 0.002$ \\
B75 & 25 & 0 & 75 & $94.15 \pm 5.05$ & $118.407 \pm 0.011$ \\
B & 0 & 0 & 100 & $96.64 \pm 3.85$ & $121.289 \pm 0.002$ \\
\hline
\end{tabular}

Figure 2 presents the correlation between $\mathrm{E}_{\mathrm{a}}$ and $\mathrm{NO}_{\mathrm{x}}$ emissions, in which is possible to observe that as activation energy increases, $\mathrm{NO}_{\mathrm{x}}$ emission also increases. When biodiesel is added to the diesel, there is an increasing of both $\mathrm{NO}_{\mathrm{x}}$ and activation energy, but when farnesane is added to diesel, a contrary behavior is observed, i.e, as the farnesane content increases in the blend, there is a lowering in both activation energy and $\mathrm{NO}_{\mathrm{x}}$ emission.

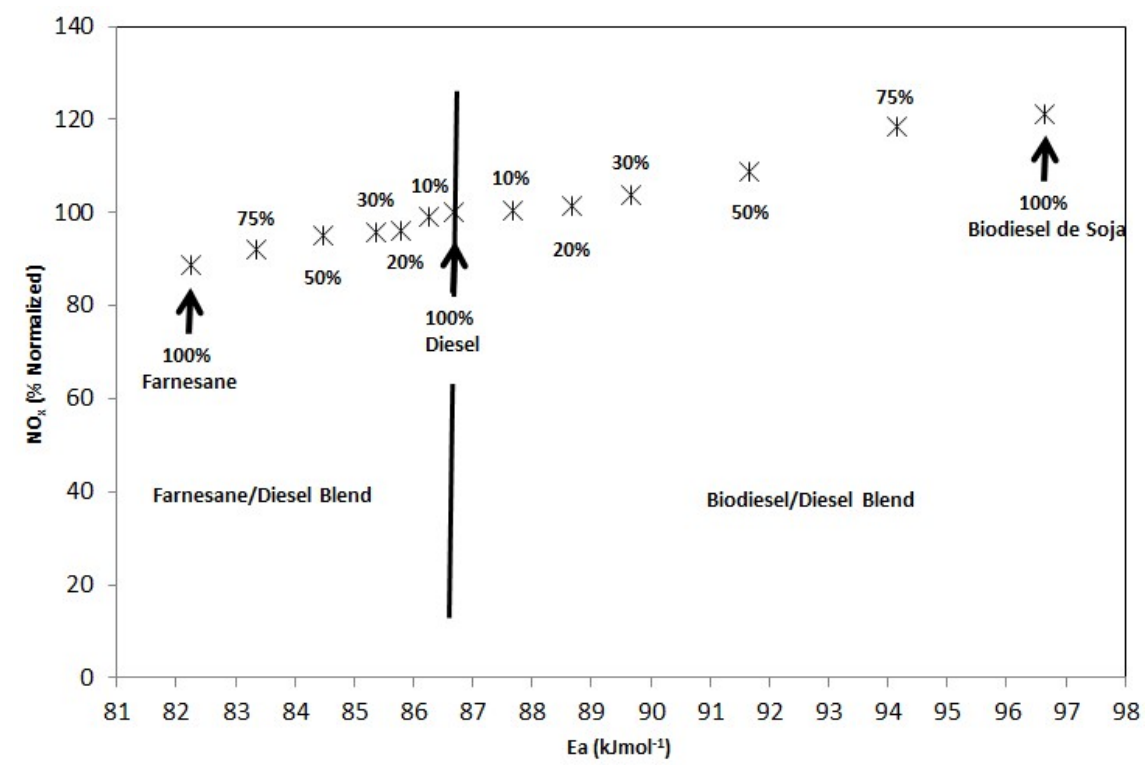

Figure 2. $\mathrm{E}_{\mathrm{a}}$ Activation energy and $\mathrm{NO}_{\mathrm{x}}$ emissions (Normalized as $100 \%$ of $\mathrm{NO}_{\mathrm{x}}$ emission for the pure fossil diesel)

The entire correlation was obtained from the combination of all values considering farnesane/Diesel and biodiesel/Diesel. A linear correlation was obtained as presented in the Equation 3. 


$$
\mathrm{NO}_{\mathrm{x}}=2.2526 \mathrm{E}_{\mathrm{a}}-96.41
$$

\subsection{CO emission}

CO emissions are described in this study as normalized values considering $100 \%$ of $\mathrm{CO}$ for pure fossil diesel. Table 4 shows $\mathrm{CO}$ emissions and Ea activation energy for pure fossil diesel, pure biodiesel, pure farnesane and their blends at five different compositions. It can be noted that the lowest value of CO emission was obtain for the diesel $25 \%$ /biodiesel $75 \%$ blend, for which $\mathrm{CO}$ emission reduced up to $36.4 \%$.

Table 4: $\quad E_{a}$ activation energy and NOx emission for diesel, farnesane and biodiesel and their blends

\begin{tabular}{cccccc}
\hline Samples & Diesel & Farnesane & Biodiesel & $\mathrm{E}_{\mathrm{a}}(\mathrm{kJ} / \mathrm{mol})$ & $\mathrm{CO}(\%)$ \\
\hline D & 100 & 0 & 0 & $86.7 \pm 8.70$ & $100.000 \pm 0.020$ \\
F10 & 90 & 10 & 0 & $86.25 \pm 8.15$ & $95.861 \pm 0.010$ \\
F20 & 80 & 20 & 0 & $85.80 \pm 7.63$ & $91.391 \pm 0.011$ \\
F30 & 70 & 30 & 0 & $85.36 \pm 7.11$ & $86.424 \pm 0.011$ \\
F50 & 50 & 50 & 0 & $84.47 \pm 6,06$ & $90.894 \pm 0.022$ \\
F75 & 25 & 75 & 0 & $83.36 \pm 4,75$ & $79.967 \pm 0.012$ \\
F & 0 & 100 & 0 & $82.24 \pm 3,44$ & $84.934 \pm 0.012$ \\
\hline B10 & 90 & 0 & 10 & $87.69 \pm 8,19$ & $99.338 \pm 0.010$ \\
B20 & 80 & 0 & 20 & $88.68 \pm 7,71$ & $89.404 \pm 0.011$ \\
B30 & 70 & 0 & 70 & $89.68 \pm 7.23$ & $82.450 \pm 0.036$ \\
B50 & 50 & 0 & 50 & $91.67 \pm 6.26$ & $69.536 \pm 0.057$ \\
B75 & 25 & 0 & 75 & $94.15 \pm 5.05$ & $63.576 \pm 0.016$ \\
B & 0 & 0 & 100 & $96.64 \pm 3.85$ & $66.556 \pm 0.030$ \\
\hline
\end{tabular}

$\mathrm{CO}$ emissions versus activation energy for all fuels are presented in the Figure 3, in which it is possible to observe that the highest emission was obtained for the pure diesel, but it is not correlated with the highest activation energy value. When farnesane is added to the fossil diesel, the activation energy decreases and $\mathrm{CO}$ emissions also decrease. However, when biodiesel is added to the fossil diesel, the activation energy increases and $\mathrm{CO}$ emissions decreases. 


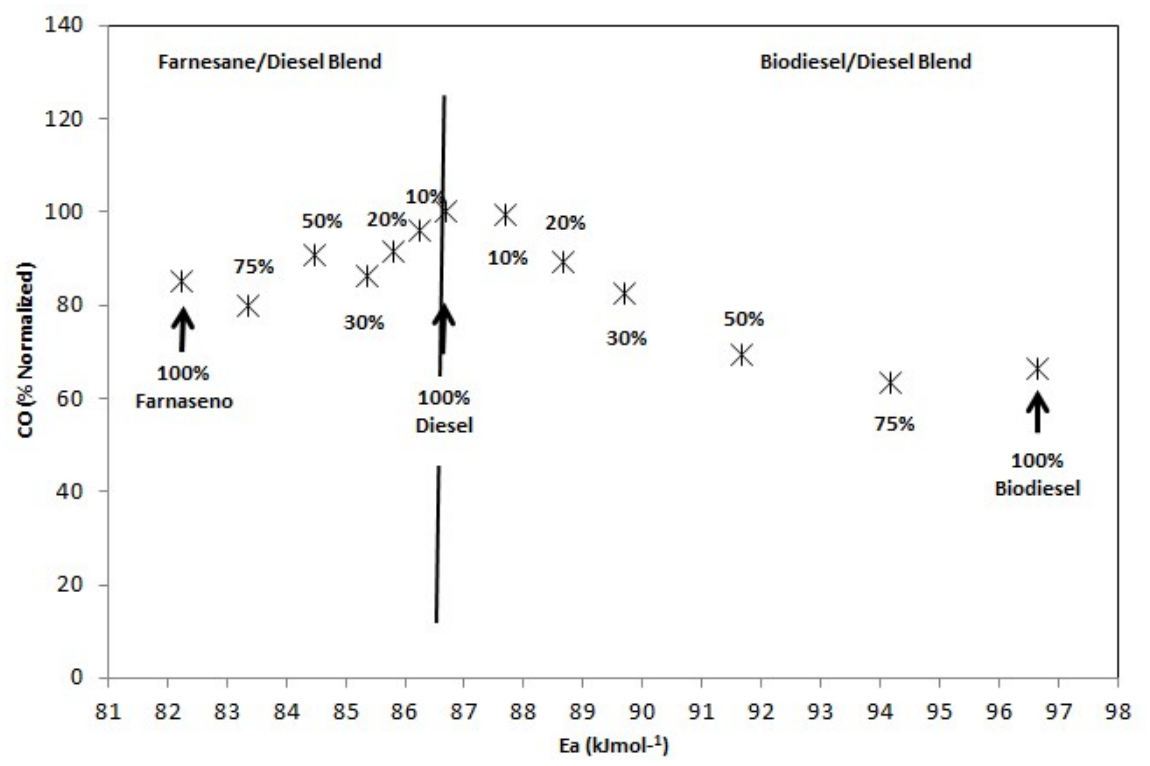

Figure 3. Ea Activation energies and CO emissions (Normalized as $100 \%$ of CO emission for the pure fossil diesel)

The entire correlation was obtained from the combination of all $\mathrm{Ea}$ and $\mathrm{CO}$ values considering farnesane/Diesel and biodiesel/Diesel. A polynomial correlation was obtained as presented in the Equation 4.

$$
C O=0.0709 E_{\alpha}^{3}-19.259 E_{\alpha}^{2}+1740.1 E_{\alpha}-52213.2508
$$

\subsection{VALIDATION OF BOTH CORRELATIONS: NOX VERSUS EA AND CO VERSUS EA}

An experimental validation was addressed to verify if the simulation of the NOx and $\mathrm{CO}$ emissions are consistent with experimental data. For this validation a single case of a tertiary mixture composed by $20 \%$ of farnesane, $70 \%$ fossil diesel and $10 \%$ biodiesel was used in the OM 926 LA CONAMA P7/EURO 5 diesel engine and, from this experiment, NOx emission was $102.09 \%$, i.e., $2.09 \%$ higher than for the pure fossil diesel and for CO, $86.4 \%$.

For this tertiary mixture Ea was calculated considering the weighted average resulting in $86.80 \mathrm{~kJ} / \mathrm{mol}$, which was applied in the Equation 3 giving the $\mathrm{NO}_{\mathrm{x}}$ value as $99.13 \%$. Equation 4 was used to predict $\mathrm{CO}$ emission and the value was $92,12 \%$.

The difference between experimental and simulated results was calculated using Equation 5 and the values were $2.98 \%$ for NOx and $5.7 \%$ for $\mathrm{CO}$.

$$
\text { difference }=\frac{(\text { experimental value }- \text { emulated value })}{\text { experimental value }} \times 100 \%
$$

From the validation, as previously described, it is possible to predict $\mathrm{NO}_{\mathrm{x}}$ and $\mathrm{CO}$ emissions for other blends (binary and tertiary mixtures) composed for farnesane, biodiesel and diesel. 
Figure 4A and 4B are a ternary graph and present the prediction of $\mathrm{NO}_{\mathrm{x}}$ and $\mathrm{CO}$ emissions, respectively, for different blends, which composition varies from $0.25 \%$ up to $80 \%$ of each fuel. In the inner part of the figures, there are calculated emissions values for the different proportions of fuels in the blend. The red arrows indicate the decreasing trend of the emission values.

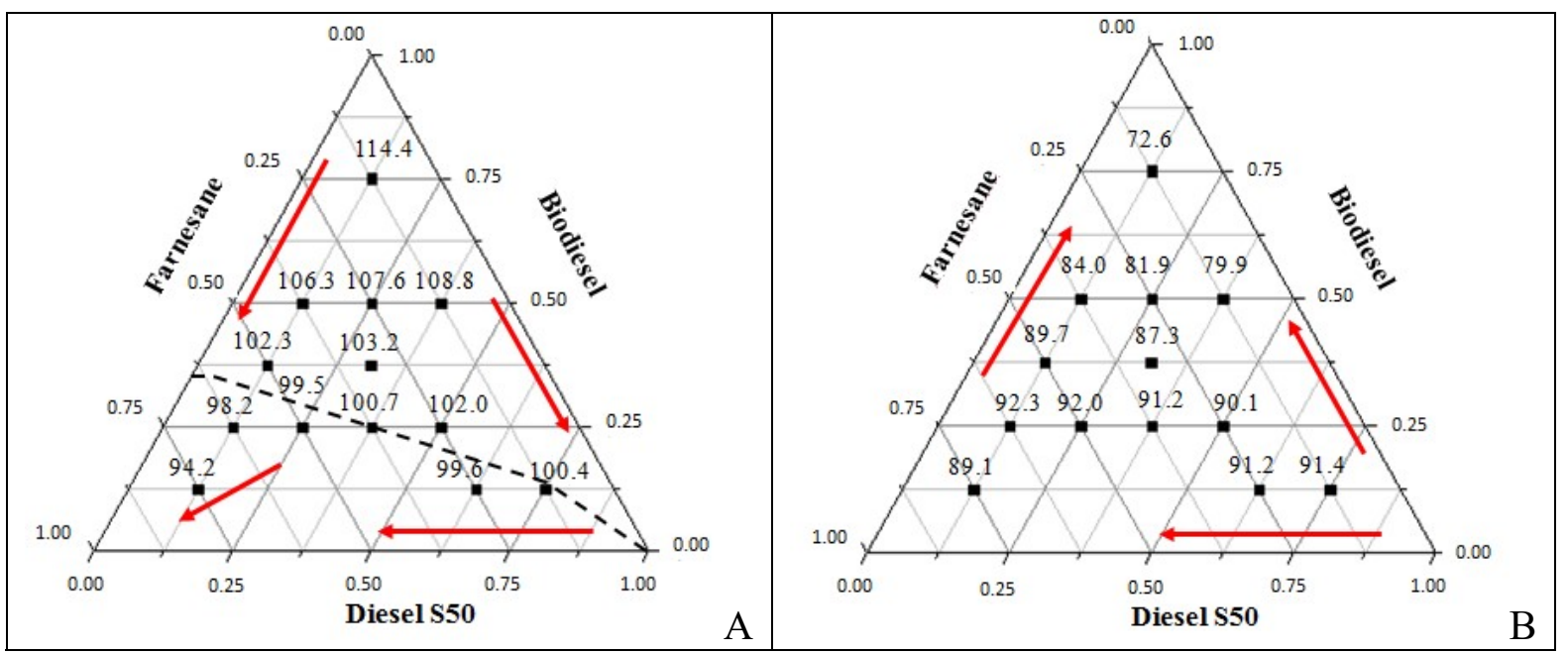

Figure 4. Ternary graph of $\mathrm{NO}_{x}(\mathrm{~A})$ and $\mathrm{CO}(\mathrm{B})$ emissions for the tertiary mixture composed by different percentages of diesel, biodiesel and farnesane.

\section{CONCLUSION.}

Results of this study showed that there is a direct correlation between activation energy and $\mathrm{NO}_{\mathrm{x}}$ emission for the biodiesel/diesel blend. When farnesane is added to diesel, there is a lowering in both activation energy and $\mathrm{NO}_{\mathrm{x}}$ emission. The highest value of $\mathrm{NO}_{\mathrm{x}}$ emission was obtained for pure biodiesel.

Related to $\mathrm{CO}$ emissions, results showed that the lowest value was obtained for biodiesel, followed by farnesane and the highest value, for pure fossil diesel.

According to the literature [12], [13] e [14], part of the $\mathrm{NO}_{\mathrm{x}}$ formation is a due to the presence of oxygen in the composition of the fuel, which contributes to the high combustion efficiency leading to an increasing of the temperature and decreasing the $\mathrm{CO}$ emissions.

$\mathrm{NO}_{\mathrm{x}}$ and $\mathrm{CO}$ emissions for the blends can be predicted from $\mathrm{E}_{\mathrm{a}}$ values, which makes an interesting tool because $\mathrm{Ea}$ is determinate at a remarkably short time according methodology described in this study, i.e., using thermogravimetric analysis (TG) and a mathematic model (Model-Free Kinetics).

\section{ACKNOWLEDGEMENTS}

The authors thank Mercedes-Benz in Brazil for supporting the work performed in its laboratory and the staff of the laboratory of Thermal and Fluids Engineering (EESC-USP) for their support in kinetic studies.

\section{REFERENCES}

[1] OZENER, O. et al. Effects of soybean biodiesel on a DI diesel engine performance, emission and combustion characteristics. Fuel, v. 115, p. 875-883, Jan 2014. ISSN 00162361. 
[2] SARAVANAN, S. et al. Correlation for thermal NOx formation in compression ignition (CI) engine fuelled with diesel and biodiesel. Energy, v. 42, n. 1, p. 401-410, 6// 2012. ISSN $0360-5442$.

[3] CONCONI, C. C.; CRNKOVIC, P. M. Thermal behavior of renewable diesel from sugar cane, biodiesel, fossil diesel and their blends. Fuel Processing Technology, v. 114, n. 0, p. 611, 10// 2013. ISSN 0378-3820.

[4] MILLO, F. et al. Influence on the performance and emissions of an automotive Euro 5 diesel engine fueled with F30 from Farnesane. Fuel, v. 138, n. 0, p. 134-142, 2014. ISSN 0016-2361.

[5] LIU, H. et al. Effects of fuel properties on combustion and emissions under both conventional and low temperature combustion mode fueling 2,5-dimethylfuran/diesel blends. Energy, v. 62, p. 215-223, 2013. ISSN 0360-5442.

[6] GROENDYK, M. A. R., D. Effects of Fuel Physical Properties on Auto-Ignition Characteristics in a Heavy Duty Compression Ignition Engine. SAE Int. J. Fuels Lubr: 200213 p. 2015.

[7] Resolução ANP 42/09 Especificação do óleo diesel 2009.

[8] DE JONG, E. et al. Promising results with YXY Diesel components in an ESC test cycle using a PACCAR Diesel engine. Biomass and Bioenergy, v. 36, n. 0, p. 151-159, 1// 2012. ISSN 0961-9534.

[9] VYAZOVKIN, S.; WIGHT, C. A. Model-free and model-fitting approaches to kinetic analysis of isothermal and nonisothermal data. Thermochimica Acta, v. 341, p. 53-68, Dec 14 1999. ISSN 0040-6031.

[10] CRNKOVIC, P. M. et al. Kinetic study of the oxidative degradation of Brazilian fuel oils. Energy \& Fuels, v. 21, n. 6, p. 3415-3419, Nov-Dec 2007. ISSN 0887-0624.

[11] GIAKOUMIS, E. G. et al. Exhaust emissions of diesel engines operating under transient conditions with biodiesel fuel blends. Progress in Energy and Combustion Science, v. 38, n. 5, p. 691-715, 10// 2012. ISSN 0360-1285.

[12] LIN, C.-Y.; LIN, S.-A. Effects of emulsification variables on fuel properties of two- and three-phase biodiesel emulsions. Fuel, v. 86, n. 1-2, p. 210-217, 1// 2007. ISSN 0016-2361. [13] QI, D. H. et al. Experimental studies on the combustion characteristics and performance of a direct injection engine fueled with biodiesel/diesel blends. Energy Conversion and Management, v. 51, n. 12, p. 2985-2992, 12// 2010. ISSN 0196-8904.

[14] VARATHARAJAN, K.; CHERALATHAN, M. Influence of fuel properties and composition on NOx emissions from biodiesel powered diesel engines: A review. Renewable and Sustainable Energy Reviews, v. 16, n. 6, p. 3702-3710, 8// 2012. ISSN 1364-0321. 